\title{
Factors that Lead to the Politicization of the American Civil Rights Movement After 1965
}

\author{
Bailun Liu \\ Dietrich school of Art and Science, University of Pittsburgh, Pittsburgh, PA,15213 USA \\ Corresponding author. Email: gaoming@cas-harbour.org
}

\begin{abstract}
The American Civil Rights Movement had reached its success and achievements during the 1960s especially with the implementation of the Civil Rights Act of 1964, which served as a landmark for the efforts of all sides. Till that moment, it seems that the Civil Rights movement relies on the grassroots, which means that people of the white and black push the American government to solve the inequality issue through their efforts. On the other hand, Civil Rights movement began to become different at that time. To be specific, the Civil Rights movement become more politicalized after 1965. For instance, one of the core themes of the Civil Rights movement after 1965 is that whether the problem of inequality between the white and black should be solved by violence, which is against the nonviolence means promoted by Dr. Martin Luther King Jr. and it means that a conflict has produced within the black community. Thus, through literature reviews and analysis, this paper comes to the conclusion that the American Civil Rights movement after 1965 becomes more politicalized because of the improper acts and implementations of the governments, the global environment such as the Cold War and founding of black political parties.
\end{abstract}

Keywords: Politicization, American Civil Rights Movement, 1965, Cold War

\section{INTRODUCTION}

The major research questions of this paper are: which factors lead to the changes of the American Civil Rights after 1965 when it achieved great success? Is the American Civil Rights Movements a civic movement or political movement after 1965? Putting it another way, these two research questions share a close relationship with the thesis statement of this paper, which defines the nature of the Civil Rights movement and the factors that lead to the changes of the movement. The reasons why these two questions are selected are first, many books and journals had written and narrated the achievements and success of the Civil Rights movement such as the March on Washington in 1963 and Dr. Martin Luther King Jr.'s "I Have a Dream" speech. Thus, the nature and change direction of the movement after 1965 worthies being discussed.

Additionally, few works discuss and explore factors that lead to the changes of the nature of the Civil Rights movement after 1965. Instead, many works focus on the American policies of the period as a whole. Even though some works have put forward the differences of the Civil Rights movement before and after 1965, they seldom mention the factors that lead to the changes. This paper will analyze why the American Civil Rights movement becomes more politicalized after 1965 through three different factors, which are the resistance between local powers and federal governments, the global environment such as the Cold War and founding of black political parties.

The main research methods that this paper employed is through literary review and analysis. First, through reviewing the previous literary works that are related to this topic, this paper could identify its research questions, which means that the reviews provide this paper with the directions and guidelines. Under this circumstance, it is found that few previous works mention the changes of the nature of Civil Rights movement and factors that lead to this change. Even though some works discuss about the differences of the Civil Rights movement before and after 1965, they did not explore deeper about the reasons or factors that are related to this change.

Second, through research, it is found out that the nature of Civil Rights movements after 1965 has changed not only because it becomes more violent, but also because it did not benefit African Americans since 
its initiative becomes different from the grassroots activities. Then, factors that lead to this change include internal and external conditions. On the one hand, external factor mainly refers to the Cold War, which highlight the problem of racism and pushes the American government to take reforms and enhance the effects of Civil Rights movement. On the other hand, internal factors include the establishments of some black organizations, which are against the non-violent means for equality and the improper implementations and acts of the American governments. The combination of the internal and external factors together leads to the changes of the nature of the Civil Rights movement after 1965.

\section{FACTORS LEAD TO THE CHANGES OF CIVIL RIGHT MOVEMENT AFTER 1965}

\subsection{Founding of Black Political Parties}

The first factor that leads to the changes of the nature of the Civil Rights movement is the founding of black political parties holding different political ideas, which means that conflicts and arguments had arisen within the black community. Fristly, with the success of Civil Rights movement in the 1960s such as the implementation of the Civil Rights Act of 1964 and Voting Rights of 1965, the founding of some black political organizations such as the Black Panther Party, the movement shifted from being non-violent as Dr. Martin Luther King Ji. claimed to be violent. For instance, in the book We Ain't what we ought to be: The Black Freedom Struggle from Emancipation to Obama, Stephen Tuck writes that "the history of American race relations is remarkably bloody" not only because the fact that so many African Americans were murdered so that even the "young Martin Luther King Jr. has a gun in his house", but also because of the "effectiveness of violence" [6]. The fact that even Dr. Martin Luther King who supports and calls for non-violence keeps a gun in his house seems to demonstrate that violence can guarantee the security and rights of African Americans.

In addition, to show the effectiveness of violence for African Americans in fighting for their rights, Tuck provides the example of the Black Power militant Lemuel Chester, who in 1967 "was accused of starting a fire that destroyed two blocks of downtown Cambridge, Maryland, but was appointed director of an expensive new community project by city officials" [6]. In other words, Lemuel Chester, as the Black Power militant was not a member of a black organization but an officer of the government. However, it to some extent, encourages violence of African Americans when Chester's behavior of destroying two blacks did not receive any punishments but a promotion the next year. Thus, when African Americans can realize their goals through violent means, some of them would not persist in the non-violent means that were previously used.

\subsection{The Improper Acts and Implementations of the Governments}

The second factor that leads to the change of nature of Civil Rights movement comes from the improper acts and implementations of the governments, which means that even though the government intends to enhance the achievements of the Civil Rights movement and provides equality for all blacks and whites, their behaviors and actions were against the intentions of the grassroots Civil Rights movement. Frist, in the article "Social Movements and Policy Implementation: The Mississippi Civil Rights Movement and the War on Poverty, 1965 to 1971 " by Kenneth T. Andrew, with the severity of the Cold War, "political outcomes provide an important indicator of the results of the Civil Rights movement in the blacks' lives" [1]. In other words, the policies in the later $1960 \mathrm{~s}$ and $70 \mathrm{~s}$ provide the implication of the changes of the nature of Civil Rights movement.

Additionally, in the article "The Long Civil Rights Movement and the Political Uses of the Past", Jacquelyn Dowd Hall describes that the race conscious remedies had some changes in the late 1960s and 1970s such as "majority-minority districts, minority business set-asides, affirmative action and two-way busing", which intend to enhance the achievements of Civil Rights movement. However, by contrast, these implements had opposite effects because they did not allow African Americans to enjoy the benefits during these periods. The reason is that these changes were made by the color-blind conservatives, who "ignored the dynamics and complexity of the movement" [4]. It is clear that from the late 1960s, policies of the American government did not play a positive role in ensuring the achievements of Civil Rights movement but instead, worsened the conditions of African Americans especially in the South. Hall explains that even though the color-blind conservatives intend to provide equality for all blacks and whites, which means that when they made policies, they did not consider the skin color of people who are related to these policies. However, these policies and acts played the opposite role so that equal rights for African Americans were not ensured. By contrast, conditions for African Americans in the South became worse and the nature of Civil Rights movement was changed as well.

\subsection{The Severity of the Cold War}

Thirdly, the severity of the Cold War, for one thing, highlighted America's problem of racism and pushed the government to take actions to enhance the effects of Civil Rights movement and for another thing, provides 
the anti-black local powers with excuses to oppose Civil Rights movement. First, in the book Cold War Civil Rights Race and the Image of American Democracy, Mary L. Dudziak writes that during the Cold War period, racism becomes an obstacle for America to realize its goals in places like Africa, Asia and Latin America so that administrations from Truman to Johnson paid great attention to the "Negro problem" [3]. In other words, civil rights for African Americans were not simply a civic issue within America but also an important international problem for America during the Cold War era. If America wants to win and get more supports from the other countries over the Soviet Union, it has to better solve the problem of racism so that Civil Rights movement after 1965 changed its nature.

In addition, according to the article "The Long Civil Rights Movement and the Political Uses of the Past", Jacquelyn Dowd Hall describes that some local powers, especially in the South who could not accept equality for African American, produced a strategy, which accuse African American civil rights leaders of being members of the Communist Party [4]. This, was an effective means against African Americans under the Cold War era because members of the Communist Party under the Cold War era have more threats to America. Therefore, the use of the Communist Party members during the Cold War era becomes an effective tool for the local powers to be against the equality of African Americans.

\section{DISCUSSION}

From the research of changes of Civil Rights Movement after 1965, it can be seen that three factors are closely related to the changes. It is certain that Civil Rights movement initially persist in non-violent principles as Dr. Martin Luther King Jr. advocates. For instance, in the book Transnational roots of the civil rights movement: African American explorations of the Gandhian repertoire, Sean Chabot writes that the SCLC leaders and activists in Birmingham greatly performed "nonviolent direct action" because they firmly performed the "main steps and procedures of satyagraha from the beginning to the end" and claimed that "the Gandhian repertoire was now deeply embedded in the American Civil Rights movement" [2]. Clearly, Chabot puts the emphasis on the nonviolence of the Civil Rights movement before 1965 but mentions little about the change of the nature of the Civil Rights movement after 1965. Thus, the nature and change direction of the movement after 1965 worthies being discussed.

Besides of the internal change, Cold War plays an important role as well. However, influence of Cold War should be temporary, but the change of how American government implements policies has a far fundamental role in the changes of Civil Rights movement even today. According to Juan Williams, the author of the book Eyes on the Prize: America's Civil Rights Years, 1954-1965, the focus of the Civil Rights movement began to change after 1965, which "shifted from the moral imperatives that had garnered support from the nation's moderates - issues including the right to vote and the right to a decent education to issues whose moral rightness was not as readily apparent such as job and housing discrimination, Johnson's war on poverty and affirmative action" [6]. In other words, Williams argues that the emphasis of the Civil Rights movement after 1965 changed from the issue between the black and white to the argument whose moral rightness is more advanced. Meanwhile, William also provides several examples to demonstrate the point. Under this circumstance, if the white can sympathize and help the black before 1965 in the Civil Rights movement, they would probably not after 1965 due to the change of the focus.

\section{CONCLUSION}

In terms of the Civil Right movement, the achievements and success such as the Civil Rights Act of 1964 and Voting Act are the mostly mentioned. It is certain that the achievements and success of Civil Rights movement cannot be denied. However, the fact that Civil Right movement after 1965 had changed cannot be denied as well. To be specific, Civil Right movement after 1965 hold different opinions from being non-violent before, its intentions were against the initiatives of the grassroot activists, and it was heavily influenced by policies and parties of the Cold War era. Subsequently, factors that lead to these changes of Civil Right movement come from internal and external sides. For one thing, the external factor is influences of the Cold War policies, which allow some groups such as the Southern local powers against Civil Rights equality to make use of African American activists. In this way, the achievements of Civil Rights movement were harmed. For another thing, internal factors come from the American government and African American groups. First, even though the American government held good initiative, its implementations and policies were not in the correct way so that the policies played opposite effects. Subsequently, African Americans did not enjoy the benefits of those policies and the results of Civil Rights movement were not ensured as well. Then, the founding of the African American communities, which claim and call for violence promoted the produce of conflicts within the black communities. Hence, internal factors and external factors allow the changes of the nature of Civil Rights movement after 1965.

However, the disadvantage of this research method is that it might lack sufficient evidence to support its argument and it can become biased if there are not enough works that support the argument. It is obvious that some factors have more related works than others 
to find and support the argument. As a result, it is possible that if there is not enough or comprehensive evidence to support, the argument might become weakened and biased.

\section{REFERENCES}

[1] Andrews, Kenneth T. Social movements and policy implementation: The Mississippi civil rights movement and the war on poverty, 1965 to 1971. American Sociological Review (2001): 71-95.

[2] Chabot, Sean. Transnational roots of the civil rights movement: African American explorations of the Gandhian repertoire. Lexington Books, 2012.

[3] Dudziak, Mary L. Cold war civil rights. Princeton University Press, 2011.

[4] Hall, Jacquelyn Dowd. The long civil rights movement and the political uses of the past. The Best American History Essays 2007. Palgrave Macmillan, New York, 2007. 235-271.

[5] Tuck, Stephen. We ain't what we ought to be: The black freedom struggle from emancipation to Obama. Harvard University Press, 2010.

[6] Williams, Juan. Eyes on the prize: America's civil rights years, 1954-1965. Penguin, 2013. 